\title{
Association of circulating 25-hydroxyvitamin D levels with hypertension and blood pressure values in Korean adults: A Mendelian randomization study on a subset of the Korea National Health and Nutrition Survey 2011-2012 population
}

\author{
So-Young Kwak ${ }^{1}$, Yoonsu Cho ${ }^{1,2}$, Hannah $\mathrm{Oh}^{1}$ and Min-Jeong Shin ${ }^{1 \mathrm{~s}}$ \\ 'Department of Public Health Sciences, BK21PLUS Program in Embodiment: Health-Society Interaction, Graduate School, Korea University, Seoul 02841, Republic \\ of Korea \\ ${ }^{2}$ MRC Integrative Epidemiology Unit, Population Health Sciences, Bristol Medical School, University of Bristol, Bristol BS8 2BN, United Kingdom
}

BACKGROUND/OBJECTIVES: Lower circulating 25-hydroxyvitamin D [25(OH)D] levels are associated with a higher risk of hypertension (HTN); however, it remains unclear whether the relationship is causal. We aimed to evaluate the causal effects of circulating 25(OH)D levels on the prevalence of HTN in the Korean population using the Mendelian randomization (MR) approach. SUBJECTS/METHODS: Epidemiological data, serum 25(OH)D data, and genomic DNA biospecimens were obtained from 2,591 participants, a subset of the study population in the Korea National Health and Nutrition Survey 2011-2012. Five 25(OH)D-related single nucleotide polymorphisms (SNPs; DHCR7 rs12785878, CYP2R1 rs10741657, CYP2R1 rs12794714, CYP24A1 rs6013897, and GC rs2282679), identified a priori from genome-wide association studies, were used as instrument variables (IVs) for serum 25(OH)D levels. In the MR analysis, we performed IV analyses using the two-stage least squares method.

RESULTS: In the observational analysis, circulating $25(\mathrm{OH}) \mathrm{D}$ levels were found to be inversely associated with the HTN prevalence in ordinary least squares models (odds ratio: $0.97,95 \%$ confidence interval: $0.96,0.99$ ) after adjusting for the potential confounders. There were differences in the circulating $25(\mathrm{OH}) \mathrm{D}$ levels across genotypes of individual SNPs. In the MR analysis, using individual SNPs as IVs, 25(OH)D levels were not associated with the HTN prevalence.

CONCLUSIONS: We found no association between genetically determined circulating 25(OH)D levels and HTN in Korean adults. Our results are listed owing to the relatively small sample size and possible weak instrument bias; therefore, further studies are needed to confirm these results.

Nutrition Research and Practice 2019;13(6):498-508; https://doi.org/10.4162/nrp.2019.13.6.498; pISSN 1976-1457 elSSN 2005-6168

Keywords: Vitamin D, hypertension, blood pressure, causality

\section{INTRODUCTION}

There have been inconsistent reports on the association between serum vitamin $D$ levels and the risk of hypertension (HTN). Meta-analyses of prospective studies [1,2] and crosssectional studies [1] have shown that low vitamin D levels are associated with an increased risk of HTN. In contrast, a meta-analysis of 30 randomized controlled trials failed to show evidence of an association, suggesting that vitamin D supplementation may not result in an overall reduction in the blood pressure (BP) value [3]. Therefore, it remains unclear whether the role of vitamin D in BP and HTN is causal.

Estimates derived from observational studies may be biased because of confounders (environmental and behavioral), systematic error, and/or reverse causation [1,2]. For example, the association between serum 25-hydroxyvitamin D [25(OH)D] levels and HTN could be explained by other factors (e.g., obesity) that affect serum $25(\mathrm{OH}) \mathrm{D}$ levels and HTN risk $[1,4,5]$. These factors may confound the association between serum 25(OH)D levels and HTN, giving biased results. Even after appropriate adjustments, we were unable to eliminate the effect of all the potential confounders. Moreover, several studies have suggested that low serum 25(OH)D levels result from disease progression, indicating the possibility of reverse causality [6]. Low serum 25(OH)D levels can be influenced by HTN onset, indicating the possibility of reverse causation $[6,7]$. Furthermore,

\footnotetext{
This research was supported by the Basic Science Research Program through the National Research Foundation of Korea (NRF) and funded by the Ministry of Education, Science, and Technology (NRF-2019R1F1A1063744) and by the Bio \& Medical Technology Development Program of the NRF funded by the Ministry of Science \& ICT (NRF-2012M3A9C4048761).

${ }^{\S}$ Corresponding Author: Min-Jeong Shin, Tel. 82-2-3290-5643, Fax. 82-2-940-2849, Email. mjshin@korea.ac.kr

Received: January 15, 2019, Revised: May 8, 2019, Accepted: June 17, 2019

This is an Open Access article distributed under the terms of the Creative Commons Attribution Non-Commercial License (http://creativecommons.org/licenses/by-nc/3.0/) which permits unrestricted non-commercial use, distribution, and reproduction in any medium, provided the original work is properly cited.
} 
several studies have suggested that serum $25(\mathrm{OH}) \mathrm{D}$ levels are a marker, rather than a cause, of disease outcome $[8,9]$.

The mendelian randomization (MR) approach was proposed to strengthen the causal inferences using genetic variants associated with an exposure phenotype as instrumental variables (IVs) [10-12]. This approach is based on Mendel's laws of segregation and independent assortment; this law states that genetic variants are randomly allocated during meiosis and these genetic variants are unlikely to be influenced by factors that bias observational studies. Therefore, the effect estimates from MR analyses are unlikely to be confounded. Reverse causation is also unlikely, because the outcome (i.e., HTN) does not determine which 25(OH)D-associated single nucleotide polymorphisms (SNPs) is inherited.

A recent large European MR study concluded that higher serum $25(\mathrm{OH}) \mathrm{D}$ levels predicted using a $25(\mathrm{OH}) \mathrm{D}$ synthesis score (DHCR7 rs12785878 and CYP2R1 rs12794714,) are associated with lower BP value and a lower risk of HTN [13]. In another study on a European population, a similar pattern of association was found with genetic variants in regions related to $25(\mathrm{OH}) \mathrm{D}$ metabolism (CYP24A1) [14]. However, the role of vitamin D in cardiovascular health, including BP and HTN, in Korean population is unclear because most studies have focused on European population. Further, to our knowledge, no study has investigated the relationship between serum vitamin $D$ levels and BP using the MR approach in the Korean population.

Here, we investigated the association of serum vitamin D levels with the HTN risk in 2,591 Korean subjects using the MR approach. We used five SNPs (DHCR7 rs12785878 Chr.11: 71456403; CYP2R1 rs10741657 Chr.11:14893332; CYP2R1 rs1279 4714 Chr.11:14892029; CYP24A1 rs6013897 Chr.20:54125940; and GC rs2282679 Chr.4:71742666,) that were identified a priori from previous genome-wide association studies (GWASs) [15, 16] and MR studies of vitamin D [17-20], as IVs for 25(OH)D levels because they had the potential to satisfy the assumptions of $\mathrm{MR}$ and these variants reportedly account for a large proportion of the difference in serum $25(\mathrm{OH}) \mathrm{D}$ levels $[15,21,22]$. These SNPs are related to the genes known to affect synthesis (DHCR7: endogenous production; CYP2R1: liver conversion) and metabolism (CYP24A1: degradation of vitamin D, GC: transportation of vitamin $D$ to target cells) of $25(\mathrm{OH}) \mathrm{D}$. Previous MR studies have used these SNPs as IVs to verify the causal effects of vitamin $D$ on the risk of multiple diseases including type 2 diabetes [17], multiple sclerosis [18], and ovarian cancer [19] in European and Chinese populations.

\section{SUBJECTS AND METHODS}

\section{Study participants}

We used data from the Korea National Health and Nutrition Examination Survey (KNHANES) 2011-2012, a nationally representative cross-sectional survey conducted by the Korea Centers for Disease Control and Prevention. A stratified multistage probability sampling design was used to obtain a nationally representative sample of Korean subjects based on the geographical area, sex, and age from a household registry. The KNHANES comprises the following three different sections: health examination, health interview, and nutrition survey.

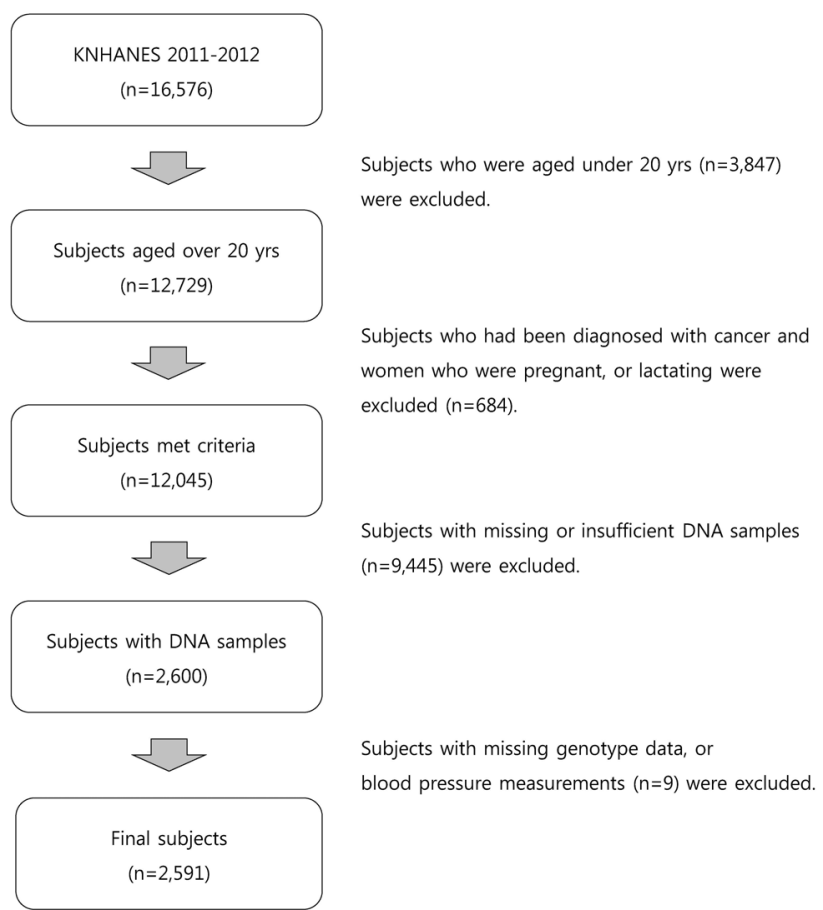

Fig. 1. Flow chart of the study participant selection

Detailed information on the KNHANES is available elsewhere [23]. Among the 16,576 participants (8,518 participants in 2011 and 8,058 participants in 2012), those aged $<20$ years were excluded. We also excluded participants who had been diagnosed with cancer and women who were pregnant or lactating. After further excluding participants with missing or insufficient DNA samples ( $n=9,445), 2,600$ eligible participants were available for genotyping. Of these, nine with had missing values in their genotype data or BP measurements were excluded. Finally, 2,591 participants (490 participants in 2011 and 2,101 participants in 2012) were included in the analyses (Fig. 1). The study protocol was approved by the institutional review board of the Korea University (KU-IRB-16-EX-272-A-1).

\section{Basic characteristics}

Sociodemographic data and lifestyle information were obtained using a health interview questionnaire, that included questions regarding sex, age, education level, smoking status, current drinking status, physical activity, and use of antihypertensive medication. The education level was categorized as follows: completed elementary school, middle school, high school, or university education. The smoking status was classified into the following four groups: never-smoked, former smoker, smokes sometimes, and smokes every day. The drinking experience was classified as "no experience of drinking (no)" or "experience of drinking (yes)." To obtain information on physical activity, the participants were asked to report the time spent on walking, moderate activity, and vigorous activity. Physical activity was defined as participation in any of the following activities: walking for $30 \mathrm{~min}$ per day for at least 5 days/week, moderate activity for $30 \mathrm{~min}$ per day for at least 5 days/week, or vigorous activity for 20 min per day for at least 
3 days/week. Use of antihypertensive medication was defined as taking antihypertensive medication at least once a month. Anthropometric information was obtained from the results of a health examination. Height and weight of the participants were measured by trained medical personnel as per standardized protocols. Body mass index (BMI) was calculated by dividing the weight in kilograms by the square of the height in meters $\left(\mathrm{kg} / \mathrm{m}^{2}\right)$. To measure biochemical markers, blood samples were collected after an 8-h fast. Serum triglyceride (TG; mg/dL), total cholesterol (TC; $\mathrm{mg} / \mathrm{dL}$ ), high-density lipoprotein cholesterol (HDL-C; mg/dL), fasting blood glucose (FBG; mg/dL), aspartate aminotransferase (AST; IU/L), and alanine aminotransferase (ALT; IU/L) levels were measured using enzymatic methods and a Hitachi automatic analyzer 7600 (Tokyo, Japan). Low-density lipoprotein cholesterol (LDL-C) levels were calculated according to the following equation: $\mathrm{LDL}-\mathrm{C}(\mathrm{mg} / \mathrm{dL})=\mathrm{TC}(\mathrm{mg} / \mathrm{dL})-\mathrm{HDL}-\mathrm{C}$ $(\mathrm{mg} / \mathrm{dL})$ - $\{[\mathrm{TG}(\mathrm{mg} / \mathrm{dL}) / 5](\mathrm{TG}<400)\}$ [24]. Glycosylated hemoglobin (HbA1c; \%) was measured using high-performance liquid chromatography (HLC-723G7; Tosch, Tokyo, Japan).

\section{Measurement of serum 25(OH)D levels}

Blood samples were collected after an 8-h fast and immediately processed, refrigerated, and transported to the central testing institute (NeoDIN Medical Institute, Seoul, Korea). Serum 25(OH)D levels were measured within $24 \mathrm{~h}$ using radioimmunoassay (RIA) using a 1470 WIZARD gamma-counter (PerkinElmer, Turku, Finland) and a 25-Hydroxyvitamin D $125 \mathrm{I}$ RIA Kit (DiaSorin, MN, USA). In the present study, serum $25(\mathrm{OH}) \mathrm{D}$ levels were considered sufficient if they were $\geq 30 \mathrm{ng} / \mathrm{mL}$, insufficient if they were between $20 \mathrm{ng} / \mathrm{mL}$ and $30 \mathrm{ng} / \mathrm{mL}$, deficient if they were between $10 \mathrm{ng} / \mathrm{mL}$ and $20 \mathrm{ng} / \mathrm{mL}$, and severely deficient if they were $<10 \mathrm{ng} / \mathrm{mL}$ [25]. Participants were divided into the following four groups based on their serum $25(\mathrm{OH}) \mathrm{D}$ levels: severe deficiency, deficiency, insufficiency, and sufficiency of serum 25(OH)D levels.

\section{$B P$ and hypertension}

Measurement of BP was performed by a trained technician using a mercury sphygmomanometer (Baumanometer, NY, USA). The BP was measured three times on the right arm, and the average values of the second and third readings were recorded as the systolic BP (SBP) and diastolic BP (DBP) measurements. Those with a self-reported history of physician-diagnosed HTN, BP $>140 / 90 \mathrm{mmHg}$, or on antihypertensive medication were defined as having HTN.

\section{Genetic variants}

Five well-known serum 25(OH)D-related SNPs (DHCR7 rs1278 5878; CYP2R1 rs10741657 and rs10741657; CYP24A1 rs6013897; and GC rs2282679) were selected from a previous GWAS [15] and MR studies $[4,13,17-20,26]$. DNA samples were extracted from the blood samples at the time of blood collection. Three vials of DNA samples (20 ug per vial) in ethylenediaminetetraacetic acid (EDTA) tube were stored in a deep freezer at $-70^{\circ} \mathrm{C}$. In 2017, about 6-7 years after the blood collection, we obtained $300 \mathrm{ng}$ DNA samples from the National Biobank of Korea where the DNA samples were stored for genotyping [27]. Genotyping for rs12785878 (DHCR7), rs10741657 and rs12794714
(CYP2R1), and rs6013897 (CYP24A1) was performed using a SNP type assay (Fluidigm, San Francisco, CA, USA), as per the manufacturer's instructions at DNALINK, INC (Seoul, Korea). Genotyping of rs2282679 (GC) was further analyzed using the TaqMan assay method with a TaqMan fluorogenic 5 ' nuclease assay ( $A B I$, Foster City, CA, USA). Detailed methods of genotyping are described elsewhere [28,29].

\section{Statistical analysis}

All the statistical analyses were performed using Stata MP 13 (Stata Corp LP, TX, USA). Data are reported as mean \pm standard error values for the continuous variables and as number of counts and percentages for the categorical variables. Differences in the characteristics were evaluated using one-way analysis of variance (ANOVA) for continuous variables and chi-squared test for categorical variables. The effect allele frequency was calculated according to the following formula: (counts of heterozygotes $+2 \times$ homozygotes of effect allele $) /(2 \times$ total counts $)$. The strength of the associations between serum $25(\mathrm{OH}) \mathrm{D}$ levels and IVs was tested using the F-statistic. We conducted both observational and MR analyses to examine the relationships of serum 25(OH)D with HTN and BP values. The observational analysis for the associations between serum 25(OH)D levels and HTN/BP was conducted using the ordinary least squares (OLS) estimation method (in logistic regression models and linear regression models, respectively), adjusted for sex, age, BMl, education level, smoking status, drinking experience, physical activity, and use of antihypertensive medication as confounders. In the MR analysis, the effects of serum 25(OH)D levels on HTN/BP were estimated using an IV analysis with the two-stage least squares method. In the first stage, the association of individual genetic variants with serum $25(\mathrm{OH}) \mathrm{D}$ levels was tested in an additive model. The fitted serum 25(OH)D levels were then regressed on HTN/BP in the second stage. In the secondary analyses, we created a composite genetic risk score (GRS) (range 0-9) to assess the polygenic contribution of the loci associated with serum $25(\mathrm{OH}) \mathrm{D}$ by summing the number of 25(OH)D-increasing alleles across the five SNPs. Weighted GRS (wGRS) (range 0-9.5) was created by weighing each allele by its effect size reported in a previous GWAS [30]. We further created two separate function-based GRSs: synthesis score (range 0-6) using three SNPs relevant for synthesis of $25(\mathrm{OH}) \mathrm{D}$ (DHCR7 rs12785878, CYP2R1 rs10741657 and rs12794714;) and metabolic score (range 0-4) using two SNPs associated with transfer and clearance of 25(OH)D (CYP24A1 rs6013897, GC rs2282679). Results are presented as odds ratios (ORs) and $95 \%$ confidence intervals (Cls) for HTN and $\beta$ coefficient and $95 \%$ Cls for BP.

\section{RESULTS}

General characteristics according to the serum 25(OH)D levels

Total 2,591 participants with both genetic and serum vitamin $D$ data were included in our analyses. The basic characteristics of the study participants included are shown in Table 1. The prevalence of vitamin D sufficiency (serum $25(\mathrm{OH}) \mathrm{D} \geq 30 \mathrm{ng} / \mathrm{mL}$ ) was very low $(n=71 ; 2.7 \%)$. There were differences in the age, sex, BMl, education level, smoking status, and use of antihyper- 
Table 1. Characteristics of the study participants as per the serum vitamin D level categories

\begin{tabular}{|c|c|c|c|c|c|}
\hline & \multicolumn{5}{|c|}{ Serum vitamin $D$ categories $(\mathrm{ng} / \mathrm{mL})$} \\
\hline & $\begin{array}{l}\text { Severe deficiency } \\
\quad(n=190)\end{array}$ & $\begin{array}{l}\text { Deficiency } \\
(n=1,733)\end{array}$ & $\begin{array}{l}\text { Insufficiency } \\
\quad(n=597)\end{array}$ & $\begin{array}{l}\text { Sufficiency } \\
(n=71)\end{array}$ & $P$-value ${ }^{\dagger}$ \\
\hline & {$[0-10] \mathrm{ng} / \mathrm{mL}$} & {$[10-20] \mathrm{ng} / \mathrm{mL}$} & {$[20-30] \mathrm{ng} / \mathrm{mL}$} & {$[\geq 30] \mathrm{ng} / \mathrm{mL}$} & \\
\hline Serum $25(\mathrm{OH}) \mathrm{D}$ levels $(\mathrm{ng} / \mathrm{mL})$ & $8.4 \pm 0.1^{\mathrm{a}}$ & $15.0 \pm 0.1^{b}$ & $23.3 \pm 0.1^{c}$ & $33.6 \pm 0.5^{d}$ & $<0.001$ \\
\hline \multicolumn{6}{|l|}{ Lifestyle variables } \\
\hline Age (yrs) & $44.8 \pm 1.1^{\mathrm{a}}$ & $48.7 \pm 0.4^{b}$ & $55.2 \pm 0.6^{c}$ & $59.5 \pm 1.6^{c}$ & $<0.001$ \\
\hline Male $(\%, n)$ & $26.8(51)$ & 45.9 (796) & $59.1(353)$ & $52.1(37)$ & $<0.001$ \\
\hline Body mass index $\left(\mathrm{kg} / \mathrm{m}^{2}\right)$ & $23.0 \pm 0.2^{\mathrm{a}}$ & $24.1 \pm 0.1^{b}$ & $24.1 \pm 0.1^{b}$ & $23.9 \pm 0.4^{\mathrm{ab}}$ & $<0.001$ \\
\hline $\begin{array}{l}\text { Education (elementary school/middle school/high school/ } \\
\text { university) (\%) }\end{array}$ & $12.6 / 13.1 / 36.6 / 37.7$ & 20.3/11.1/37.0/31.7 & $32.0 / 15.7 / 30.2 / 22.1$ & $35.2 / 18.3 / 31.0 / 15.5$ & $<0.001$ \\
\hline Smoking status (never/former/sometimes/daily) (\%) & $69.2 / 11.5 / 0.6 / 18.7$ & $57.2 / 19.9 / 2.2 / 20.7$ & $45.9 / 29.4 / 1.0 / 23.7$ & 49.3/23.9/4.2/22.5 & $<0.001$ \\
\hline Drinking experience (no/yes) (\%) & $9.9 / 90.1$ & $10.8 / 89.2$ & $12.6 / 87.4$ & 18.3/81.7 & 0.150 \\
\hline Physical activity (\%, n) & $45.6(83)$ & $44.9(764)$ & $47.8(277)$ & $47.9(34)$ & 0.659 \\
\hline Use of antihypertensive medication $(\%, \mathrm{n})$ & $19.7(36)$ & $19.1(323)$ & $26.5(152)$ & $31.0(22)$ & $<0.001$ \\
\hline \multicolumn{6}{|l|}{ Cardiovascular risk factors } \\
\hline $\mathrm{TG}(\mathrm{mg} / \mathrm{dL})^{*}$ & $131.9 \pm 7.1$ & $139.7 \pm 3.0$ & $136.6 \pm 3.2$ & $129.4 \pm 10.1$ & 0.336 \\
\hline $\mathrm{TC}(\mathrm{mg} / \mathrm{dL})$ & $183.1 \pm 2.5$ & $189.9 \pm 0.9$ & $190.8 \pm 1.4$ & $184.5 \pm 4.6$ & 0.036 \\
\hline $\mathrm{HDL}-\mathrm{C}(\mathrm{mg} / \mathrm{dL})$ & $49.5 \pm 0.9$ & $49.7 \pm 0.3$ & $49.1 \pm 0.5$ & $48.2 \pm 1.4$ & 0.592 \\
\hline LDL-C (mg/dL) & $108.2 \pm 2.3$ & $113.7 \pm 0.8$ & $114.5 \pm 1.4$ & $110.6 \pm 4.2$ & 0.094 \\
\hline FBG $(\mathrm{mg} / \mathrm{dL})^{*}$ & $95.4 \pm 1.2^{\mathrm{a}}$ & $99.0 \pm 0.5^{\mathrm{ab}}$ & $100.1 \pm 0.8^{\mathrm{b}}$ & $101.0 \pm 2.2^{\mathrm{b}}$ & 0.011 \\
\hline HbA1c (\%)* & $5.62 \pm 0.05^{\mathrm{a}}$ & $5.77 \pm 0.02^{\mathrm{ab}}$ & $5.85 \pm 0.03^{\mathrm{ab}}$ & $5.93 \pm 0.09^{b}$ & 0.002 \\
\hline AST (IU/L)* & $22.6 \pm 2.2^{\mathrm{a}}$ & $22.9 \pm 0.4^{\mathrm{a}}$ & $23.6 \pm 0.4^{b}$ & $25.6 \pm 1.3^{b}$ & $<0.001$ \\
\hline ALT (IU/L)* & $22.2 \pm 4.1^{\mathrm{a}}$ & $22.7 \pm 0.5^{b}$ & $22.0 \pm 0.6^{b}$ & $25.7 \pm 2.5^{b}$ & $<0.001$ \\
\hline
\end{tabular}

Values are expressed as means \pm standard errors for continuous variables and number of counts and percentages for categorical variables,

† Statistical differences among the vitamin D groups were determined using one-way ANOVA with Bonferroni's multiple comparison for continuous variables and chi-squared test for categorical variables.

* Tested after log-transformation.

TG, triglycerides; TC, total cholesterol; HDL-C, high-density lipoprotein cholesterol; LDL-C, low-density lipoprotein cholesterol; FBG, fasting blood glucose; Hb1Ac, glycosylated hemoglobin A1c; AST, aspartate aminotransferase; ALT, alanine aminotransferase.

tensive medication among the groups stratified as per the serum 25(OH)D levels. However, there were no differences in their drinking experience and physical activity levels. Analyses of the biochemical risk markers showed that TC, FBG, HbA1c, AST, and ALT levels were different among the serum 25(OH)D groups. However, these differences were attenuated after adjustment for sex and age (data not shown).

General characteristics as per the genotype of serum vitamin D-related SNPS

Genotypes are randomly assigned at conception; therefore, IVs are unlikely to be related to the potential confounders. To confirm the lack of association between the IVs and the potential confounders (one of the assumptions for IV), we compared the distributions of the participant characteristics by genotypes (Table 2). For each SNP, the potential confounders such as age, sex, BMl, education level, smoking status, drinking experience, physical activity, use of antihypertensive medication, and biochemical risk markers did not differ by genotypes.

\section{Association between the vitamin D-related SNPs and serum} 25(OH)D levels

Table 3 summarizes the genetic information of the five vitamin D-related SNPs. Serum 25(OH)D-increasing alleles were termed effect alleles, and their frequencies are presented. For all five SNPs, 25(OH)D-increasing alleles were positively associated with serum $25(\mathrm{OH}) \mathrm{D}$ levels, as shown by $\beta$ coefficients. Of these, the associations were strongest for rs2282679 (per allele: $\beta=$ $0.639 \mathrm{ng} / \mathrm{mL}$, F-statistics $=14.31, P<0.001$ ) and rs12785878 (per allele: $\beta=0.579 \mathrm{ng} / \mathrm{mL}, F$-statistics $=13.34, P<0.001$ ). Other three SNPs (rs10741657, rs12794714, rs6013897) had F-statistics $<10$, demonstrating the possibility of weak instrument bias.

Association of the serum 25(OH)D levels with HTN and elevated $B P$ : Observational and MR estimates

The association between circulating 25(OH)D levels and HTN is presented in Table 4. In the observational analysis, serum 25(OH)D levels were associated with a decreased prevalence of HTN (per $1 \mathrm{ng} / \mathrm{mL}$ increase: OR: $0.97,95 \% \mathrm{Cl}$ : 0.94, 0.99) in the OLS models. SBP was inversely associated with serum 25(OH)D levels ( $\beta$ : $-0.13 \mathrm{mmHg}, 95 \% \mathrm{Cl}:-0.24,-0.03)$; however, DBP did not show such an association. The MR analysis showed no strong pattern of association between the serum 25(OH)D levels and HTN using individual SNPs as IVs. Although the Cls were wide, genetically determined serum 25(OH)D levels tended to be inversely associated with SBP but not with DBP. For rs6013897 (CYP24A1), the association tended to be inverse with both HTN (OR: $0.76,95 \% \mathrm{Cl}: 0.26,2.25)$ and BP ( $\beta$ : -5.46 $\mathrm{mmHg}, 95 \% \mathrm{Cl}$ : -23.7 to 12.8 for SBP; $\beta$ : $-2.08 \mathrm{mmHg}, 95 \% \mathrm{Cl}$ : -10.1 to 5.93 for DBP). Similar results were observed for the GRSs (Supplementary Table 1 and 2). 


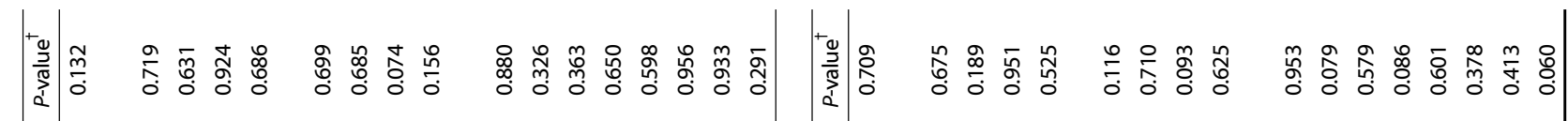

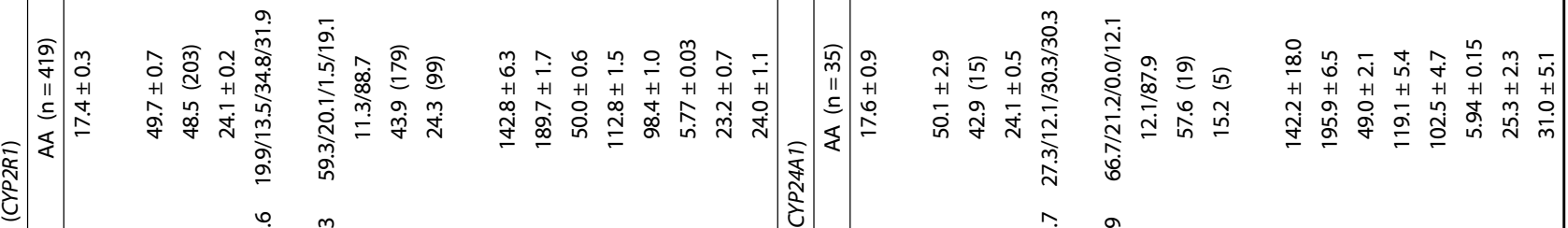

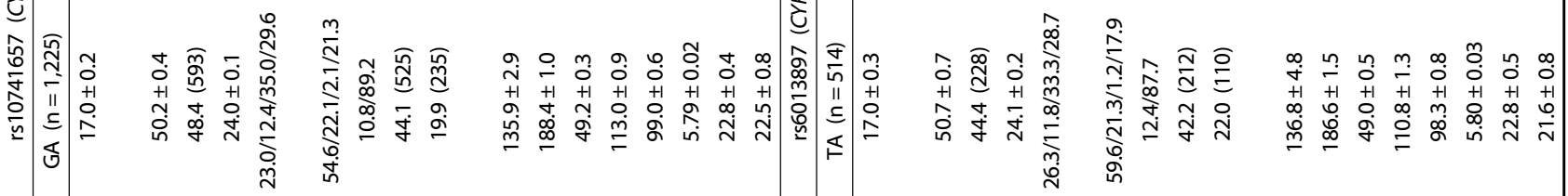

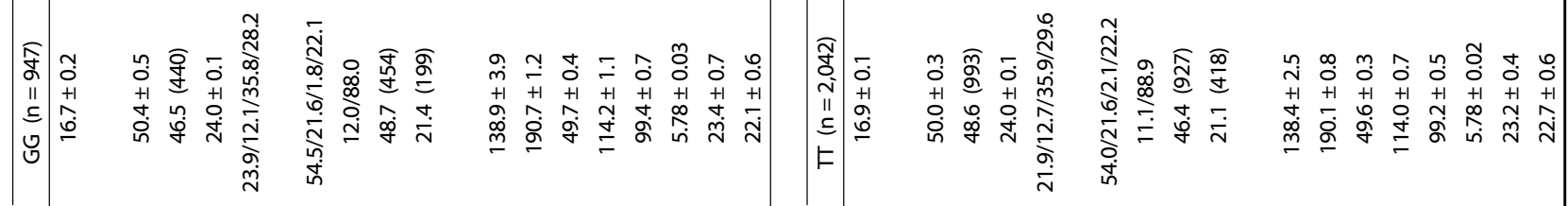
善言

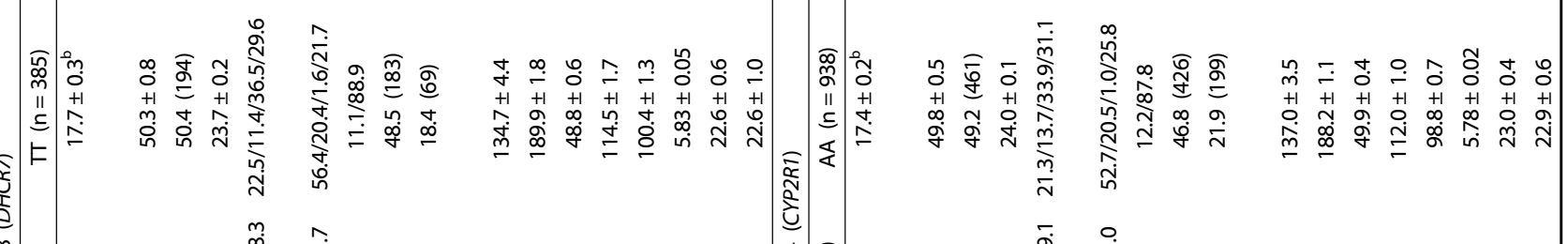

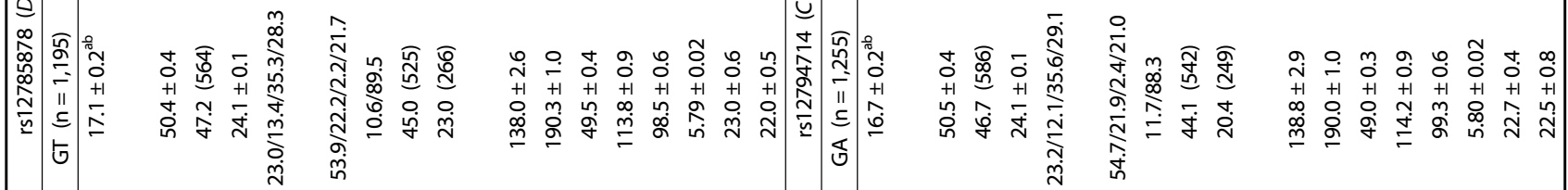

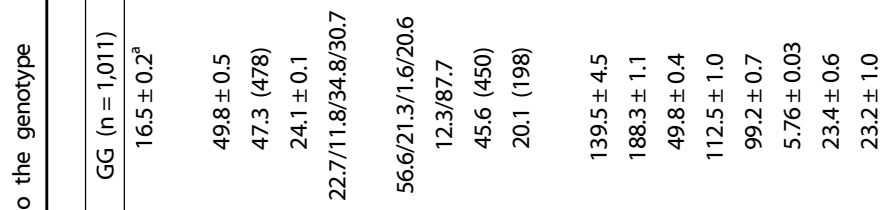




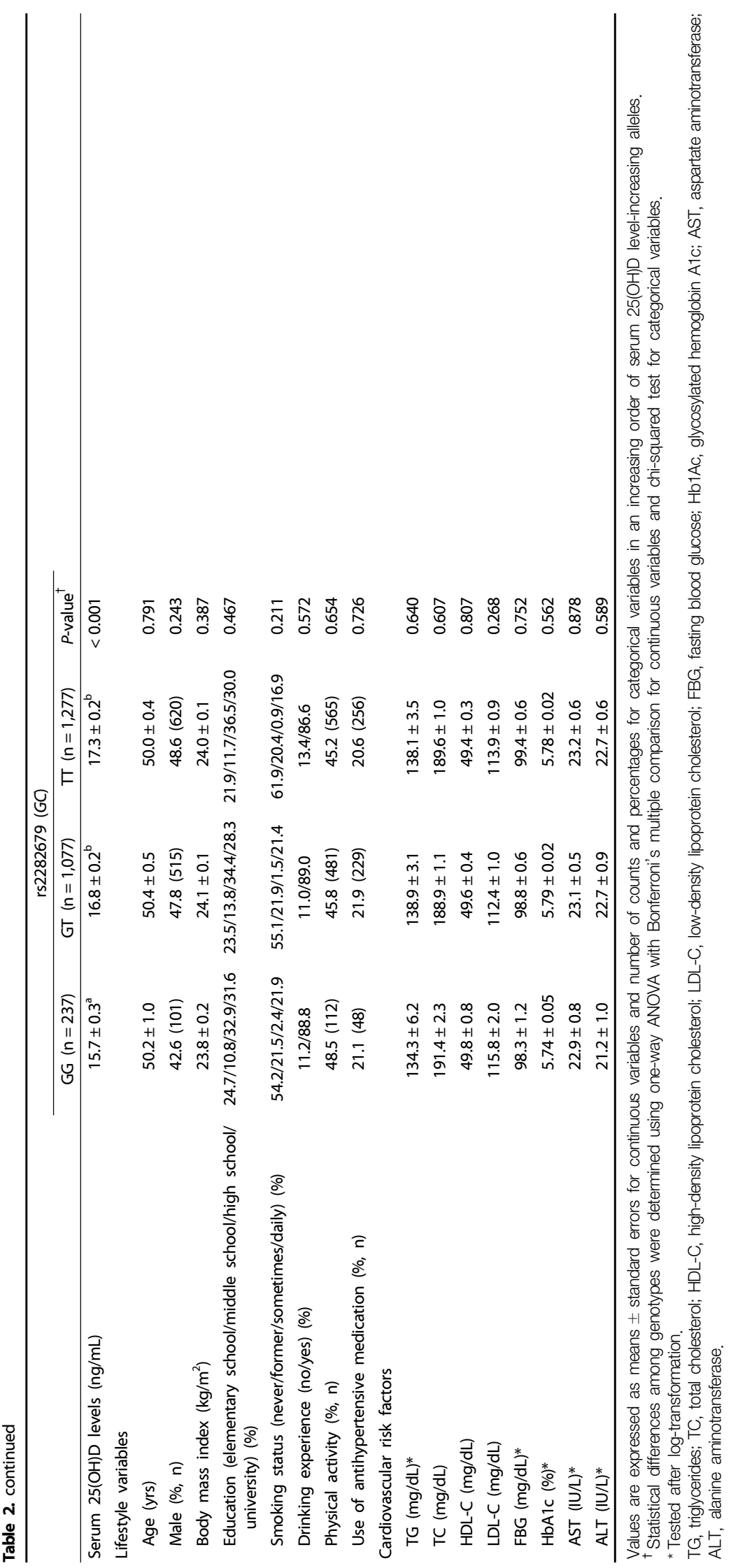


Table 3. Characteristics of single nucleotide polymorphisms used as an instrumental variable for serum $25(\mathrm{OH}) \mathrm{D}$ levels

\begin{tabular}{|c|c|c|c|c|c|c|c|}
\hline SNP & Nearest gene & Chr & $\begin{array}{l}\text { Serum } 25(\mathrm{OH}) \mathrm{D} \\
\text { increasing allele }\end{array}$ & EAF & F-statistic $^{\dagger}$ & $\beta$ coefficient $^{\dagger}$ & $P$-value ${ }^{\dagger}$ \\
\hline rs12785878 & $D H C R 7$ & 11 & $\mathrm{~T}$ & 0.379 & 13.34 & 0.579 & $<0.001$ \\
\hline rs10741657 & CYP2R1 & 11 & A & 0.398 & 3.97 & 0.315 & 0.046 \\
\hline rs12794714 & CYP2R1 & 11 & A & 0.605 & 7.04 & 0.425 & 0.008 \\
\hline rs6013897 & CYP24A1 & 20 & A & 0.113 & 0.48 & 0.170 & 0.488 \\
\hline rs2282679 & GC & 4 & $\mathrm{~T}$ & 0.701 & 14.31 & 0.639 & $<0.001$ \\
\hline
\end{tabular}

${ }^{\dagger}$ F-statistic, $\beta$ coefficient, and $P$-value were obtained from the first-stage regression of serum 25(OH)D levels on genotype. SNP, single nucleotide polymorphism; Chr, Chromosome; EAF, Effect allele frequency.

Table 4. Ordinary least square estimates and instrumental variable estimates for the relationships between serum $25(\mathrm{OH}) \mathrm{D}$ levels and hypertension outcomes

\begin{tabular}{|c|c|c|c|c|c|c|}
\hline & \multirow{2}{*}{\multicolumn{2}{|c|}{ Disease hypertension }} & \multicolumn{4}{|c|}{ Blood pressure } \\
\hline & & & \multicolumn{2}{|l|}{$\mathrm{SBP}(\mathrm{mmHg})$} & \multicolumn{2}{|c|}{$\mathrm{DBP}(\mathrm{mmHg})$} \\
\hline & OR $(95 \% \mathrm{Cl})$ & $P$-value & $\beta$ coefficient $(95 \% \mathrm{Cl})$ & $P$-value & $\beta$ coefficient $(95 \% \mathrm{Cl})$ & $P$-value \\
\hline \multicolumn{7}{|l|}{$\mathrm{OLS}_{\text {estimation }}^{\dagger}$} \\
\hline Serum 25(OH)D (Per 1 ng/mL increase) & $0.97(0.94,0.99)$ & 0.01 & $-0.13(-0.24,-0.03)$ & 0.01 & $-0.06(-0.13,0.01)$ & 0.13 \\
\hline \multicolumn{7}{|l|}{ IV estimation $^{\ddagger}$} \\
\hline rs12785878 (DHCR7; T allele) & $1.05(0.86,1.29)$ & 0.61 & $0.81(-0.83,2.45)$ & 0.33 & $-0.47(-1.52,0.58)$ & 0.38 \\
\hline rs10741657 (CYP2R1; A allele) & $1.10(0.76,1.60)$ & 0.61 & $-1.72(-5.26,1.82)$ & 0.34 & $0.44(-1.46,2.34)$ & 0.65 \\
\hline rs12794714 (CYP2R1; A allele) & $1.03(0.78,1.36)$ & 0.84 & $-1.24(-3.72,1.24)$ & 0.33 & $0.55(-0.90,2.00)$ & 0.46 \\
\hline rs6013897 (CYP24A1; A allele) & $0.76(0.26,2.25)$ & 0.62 & $-5.46(-23.7,12.8)$ & 0.56 & $-2.08(-10.1,5.93)$ & 0.61 \\
\hline rs2282679 (GC; T allele) & $1.03(0.84,1.25)$ & 0.78 & $-0.44(-1.94,1.24)$ & 0.67 & $0.05(-0.93,1.03)$ & 0.92 \\
\hline
\end{tabular}

${ }^{\dagger}$ Odds ratio $(\mathrm{OR})$ and $\beta$ coefficients were obtained from standard regressions using the OLS estimation method (in logistic regression models and linear regression models, respectively). Models were adjusted for sex, age, BMl, education level, smoking status, drinking experience, physical activity, and use of antihypertensive medication as confounders.

${ }^{\ddagger} \mathrm{OR}$ and $\beta$ coefficients were obtained from IV regressions using two-stage least squares estimation method (in logistic regression models and in linear regression models, respectively), using individual genetic variants as instrument variables for serum 25(OH)D levels per serum 25(OH)D-increasing allele.

SBP, systolic blood pressure; DBP, diastolic blood pressure; OLS, ordinary least square; OR, odds ratio; 95\% Cl, 95\% confidence interval.

\section{DISCUSSION}

The main finding of this study was that there was no association between the serum 25(OH)D levels and HTN in Korean population in a framework of MR. However, our observational analyses from the same data showed that serum $25(\mathrm{OH}) \mathrm{D}$ levels were inversely associated with both HTN and SBP, consistent with the findings from other observational studies $[1,28,29]$. A cross-sectional analysis of the KNHANES 2009-2012 data showed an inverse association between vitamin $D$ levels and HTN in young and middle-aged Korean women (OR: 0.93, $95 \%$ Cl: $0.58,0.91$ ) [31]. In another study on middle-aged Korean adults, 3,234 participants with normal BP were followed up for 4 years and those with serum vitamin $D$ levels less than the median value had a higher risk of HTN (OR: $2.74,95 \% \mathrm{Cl}: 1.40$, 5.34) [32]. Similarly, most studies in Western populations have reported an inverse association between the serum $25(\mathrm{OH}) \mathrm{D}$ levels and incident HTN [2,33]. However, results from these observational analyses are prone to bias because of confounding factors and reverse causation.

The lack of association between genetically determined serum 25(OH)D and HTN observed in the present study is inconsistent with results from previous MR studies of European and NorthAmerican populations that report a favorable association between an increase in genetically instrumented $25(\mathrm{OH}) \mathrm{D}$ levels with HTN and BP values $[13,14]$. The difference in the associations may be explained by the biological differences in the ability of vitamin $D$ synthesis and metabolism among different racial groups [34]. Awumey et al. [35] reported that Indians have altered vitamin D endocrine systems and lower serum $25(\mathrm{OH}) \mathrm{D}$ levels than Caucasians. The lack of association with HTN in our study can also be explained by the limited sample size and possible weak instrument bias. Our data showed that three of five SNPs (rs10741657, rs12794714, rs6013897) were only weakly associated with the serum $25(\mathrm{OH}) \mathrm{D}$ levels (F-statistics $<10$ ); thus, these SNPs may have been weak instruments leading to underestimation of the associations with HTN. Using BP as an outcome, we found a general tendency for inverse associations between genetically determined vitamin $D$ levels and SBP, possibly due to an increased power in the analyses using continuous variables. To overcome problems with weak instrument bias and increase the statistical power, we used GRSs (weighted GRS, synthesis score, and metabolism score) as IVs. The strength of the IV assessed using F-statistic was increased from 12.68 (metabolism score) to 27.18 (wGRS). However, the results of the GRSs analyses consistently disprove a causal role of vitamin D in BP.

Violation of the assumption of IVs (pleiotropy) can result in several biases [36]. Pleiotropy occurs when the genetic variant affects the outcome through biological pathways other than the targeted mechanism of interest. It has been reported that $D H C R 7$ and CYP2R1 genes are valid for the assumption of exclusion restriction [21]. However, DHCR7 gene encodes enzymeconverting 7-dehydrocholesterol to cholesterol involved in cholesterol synthesis [21,37], thus the possibility of pleiotropy cannot be completely ruled out. However, DHCR7 was not 
associated with the serum cholesterol level in our study (Table 2; $P$-value $=0.328)$, and a previous large GWAS study of blood lipid [38] did not identify genome-wide significant association with DHCR7 gene. CYP2R1 gene encodes the vitamin D 25-hydroxylase enzyme that converts vitamin $D$ to $25(\mathrm{OH}) \mathrm{D}$ [39]. CYP2R1 is directly and biologically associated with the serum vitamin D levels; thus, it could be the best IV for MR studies on vitamin D [21]. Previous MR studies have demonstrated biological evidence of pleiotropy in two genes (CYP24A1 and $G C)$ involved in the metabolism of vitamin D [13,21]. These genes reportedly control the free vitamin $D$ levels through a feedback-loop [40]. By examining the association between genotypes and biomarkers, we tested whether pleiotropy would occur in our study. Based on the results shown in Table 2, there was no significant association between genotypes and biomarkers except for serum vitamin D levels. This can partially support that these genes influence the outcome only through serum vitamin D levels. We additionally conducted the MR-Egger test for pleiotropy [41]. The results showed no evidence of pleiotropy according to the intercept of MR-Egger $(P=0.74)$.

To our knowledge, this is the first study to examine the causal effects of serum 25(OH)D levels on HTN and BP in a Korean population using the MR approach. This study has several strengths. In the MR analyses, bias due to confounding factors and reverse causation is likely to be reduced. The concept of randomly allocated genotypes at conception (Mendel's law of independent assortment) is similar to that in a randomized controlled trial, in which the exposure is randomly assigned to each group [42]. Within both frameworks, individuals are assigned to random groups with balanced distributions of factors that generally confound the relationship between serum vitamin D levels and HTN. In addition, MR is unaffected by reverse causation because of the clear temporal sequence between the genotype and the outcome. Our results showed that each IV was independent of the potential confounders that we evaluated, including age, sex, BMl, education level, smoking status, drinking experience, physical activity, and use of antihypertensive medication. Thus, our results are unlikely to be confounded by these factors, although we cannot eliminate the possibility of confounding even in MR analysis. Further, contrary to a single measurement of serum $25(\mathrm{OH}) \mathrm{D}$ level used in the observational analyses, genetically determined vitamin D level used in the MR analyses had a lower measurement error, was less likely to be influenced by season or region (e.g., latitude) in which the blood samples were collected, and was more likely to represent lifelong exposure levels of vitamin D. Despite these strengths, this study has certain limitations. Genetic variants used as IVs in our study were not selected from an East Asian GWAS because previous GWASs on serum 25(OH)D levels were limited to European and South Asian populations $[15,16,43,44]$. However, a recent MR study on a Chinese population has demonstrated the associations of these SNPs with circulating vitamin D levels [17], supporting the use of these SNPs as IVs in East Asian subjects. In this study on a Korean population, we also confirmed that each SNP was associated with the serum 25(OH)D levels and the directions of association were consistent with previous studies $[15,16]$.

In conclusion, this study does not support the causal effects of circulating 25(OH)D levels on HTN in Korean adults. The lack of association observed in the present MR study could be attributed to the relatively small sample size and possible weak instrument bias. However, to our knowledge, this is the only data set available for examining the associations among genotype, serum $25(\mathrm{OH}) \mathrm{D}$ levels, and HTN in the general Korean population. Our study contributes to the understanding of the association between serum $25(\mathrm{OH}) \mathrm{D}$ levels and prevalence of HTN, the prevalence of which has been continuously increasing in the Korean population. However, further MR studies with larger sample sizes are required for confirming the present results.

\section{ACKNOWLEDGMENTS}

The authors thank George Davey Smith, University of Bristol, UK, for the careful review and critical comments on the manuscript. Bioresources for the study were provided by the National Biobank of Korea and the Centers for Disease Control and Prevention, Republic of Korea (KBP-2016-062).

\section{CONFLICT OF INTEREST}

The authors declare no potential conflicts of interests.

\section{ORCID}

So-Young Kwak: https://orcid.org/0000-0003-4046-5251

Yoonsu Cho: https://orcid.org/0000-0001-6118-6652

Hannah Oh: https://orcid.org/0000-0002-8368-3032

Min-Jeong Shin: https://orcid.org/0000-0002-8952-4008

\section{REFERENCES}

1. Ke L, Mason RS, Kariuki M, Mpofu E, Brock KE. Vitamin D status and hypertension: a review. Integr Blood Press Control 2015;8:13-35.

2. Kunutsor SK, Apekey TA, Steur M. Vitamin D and risk of future hypertension: meta-analysis of 283,537 participants. Eur J Epidemiol 2013;28:205-21

3. Golzarand M, Shab-Bidar S, Koochakpoor G, Speakman J R, Djafarian $\mathrm{K}$. Effect of vitamin D3 supplementation on blood pressure in adults: an updated meta-analysis. Nutr Metab Cardiovasc Dis 2016;26: 663-73.

4. Vimaleswaran KS, Berry DJ, Lu C, Tikkanen E, Pilz S, Hiraki LT, Cooper JD, Dastani Z, Li R, Houston DK, Wood AR, Michaëlsson K, Vandenput L, Zgaga L, Yerges-Armstrong LM, McCarthy MI, Dupuis J, Kaakinen M, Kleber ME, Jameson K, Arden N, Raitakari O, Viikari J, Lohman KK, Ferrucci L, Melhus H, Ingelsson E, Byberg L, Lind L, Lorentzon M, Salomaa V, Campbell H, Dunlop M, Mitchell BD, Herzig $\mathrm{KH}$, Pouta A, Hartikainen AL, Streeten EA, Theodoratou E, Jula A, Wareham NJ, Ohlsson C, Frayling TM, Kritchevsky SB, Spector TD, Richards JB, Lehtimäki T, Ouwehand WH, Kraft P, Cooper C, März W, Power C, Loos RJ, Wang TJ, Järvelin MR, Whittaker JC, Hingorani AD, Hyppönen E; Genetic Investigation of Anthropometric Traits-GIANT Consortium. Causal relationship between obesity and vitamin D status: bi-directional Mendelian randomization analysis of multiple cohorts. PLoS Med 2013;10:e1001383.

5. Scragg R, Holdaway I, Jackson R, Lim T. Plasma 25-hydroxyvitamin 
$D_{3}$ and its relation to physical activity and other heart disease risk factors in the general population. Ann Epidemiol 1992;2:697-703.

6. Autier P, Boniol M, Pizot C, Mullie P. Vitamin D status and ill health: a systematic review. Lancet Diabetes Endocrinol 2014;2:76-89.

7. Skaaby $T$, Husemoen LL, Martinussen T, Thyssen JP, Melgaard M, Thuesen BH, Pisinger $C$, Jørgensen $T$, Johansen JD, Menné T, Carlsen $B$, Szecsi PB, Stender S, Fenger RV, Fenger M, Linneberg A. Vitamin D status, filaggrin genotype, and cardiovascular risk factors: a Mendelian randomization approach. PLoS One 2013;8:e57647.

8. Gama R, Waldron JL, Ashby HL, Cornes MP, Bechervaise J, Razavi C, Thomas OL, Chugh S, Deshpande S, Ford C. Hypovitaminosis D and disease: consequence rather than cause? BMJ 2012;345:e5706.

9. Guessous I. Role of vitamin D deficiency in extraskeletal complications: predictor of health outcome or marker of health status? BioMed Res Int 2015;2015:563403.

10. Davey Smith G, Hemani G. Mendelian randomization: genetic anchors for causal inference in epidemiological studies. Hum Mol Genet 2014;23:R89-98.

11. Smith GD, Ebrahim S. 'Mendelian randomization': can genetic epidemiology contribute to understanding environmental determinants of disease? Int J Epidemiol 2003;32:1-22.

12. Davies NM, Holmes MV, Davey Smith G. Reading Mendelian randomisation studies: a guide, glossary, and checklist for clinicians. BMJ 2018;362:k601.

13. Vimaleswaran KS, Cavadino A, Berry DJ; LifeLines Cohort Study Investigators, Jorde R, Dieffenbach AK, Lu C, Alves AC, Heerspink $\mathrm{HJ}$, Tikkanen E, Eriksson J, Wong A, Mangino M, Jablonski KA, Nolte IM, Houston DK, Ahluwalia TS, van der Most PJ, Pasko D, Zgaga L, Thiering E, Vitart V, Fraser RM, Huffman JE, de Boer RA, Schöttker B, Saum KU, McCarthy MI, Dupuis J, Herzig KH, Sebert S, Pouta A, Laitinen J, Kleber ME, Navis G, Lorentzon M, Jameson K, Arden N, Cooper JA, Acharya J, Hardy R, Raitakari O, Ripatti S, Billings LK, Lahti J, Osmond C, Penninx BW, Rejnmark L, Lohman KK, Paternoster L, Stolk RP, Hernandez DG, Byberg L, Hagström E, Melhus $H$, Ingelsson $E$, Mellström D, Ljunggren $O$, Tzoulaki I, McLachlan S, Theodoratou E, Tiesler CM, Jula A, Navarro P, Wright AF, Polasek O; International Consortium for Blood Pressure (ICBP), Cohorts for Heart and Aging Research in Genomic Epidemiology (CHARGE) Consortium; Global Blood Pressure Genetics (Global BPGen) Consortium; Caroline Hayward, Wilson JF, Rudan I, Salomaa V, Heinrich J, Campbell H, Price JF, Karlsson M, Lind L, Michaëlsson K, Bandinelli S, Frayling TM, Hartman CA, Sørensen TI, Kritchevsky $\mathrm{SB}$, Langdahl BL, Eriksson JG, Florez JC, Spector TD, Lehtimäki T, Kuh D, Humphries SE, Cooper C, Ohlsson C, März W, de Borst MH, Kumari $M$, Kivimaki $M$, Wang TJ, Power $C$, Brenner $H$, Grimnes $G$, van der Harst $P$, Snieder $H$, Hingorani $A D$, Pilz $S$, Whittaker JC, Järvelin MR, Hyppönen $E$. Association of vitamin $D$ status with arterial blood pressure and hypertension risk: a mendelian randomisation study. Lancet Diabetes Endocrinol 2014;2:719-29.

14. Kunutsor SK, Burgess S, Munroe PB, Khan H. Vitamin D and high blood pressure: causal association or epiphenomenon? Eur J Epidemiol 2014;29:1-14.

15. Wang TJ, Zhang F, Richards JB, Kestenbaum B, van Meurs JB, Berry D, Kiel DP, Streeten EA, Ohlsson C, Koller DL, Peltonen L, Cooper JD, O'Reilly PF, Houston DK, Glazer NL, Vandenput L, Peacock M, Shi J, Rivadeneira F, McCarthy Ml, Anneli $\mathrm{P}$, de Boer IH, Mangino M, Kato B, Smyth DJ, Booth SL, Jacques PF, Burke GL, Goodarzi $\mathrm{M}$, Cheung $\mathrm{CL}$, Wolf M, Rice K, Goltzman D, Hidiroglou N, Ladouceur
M, Wareham NJ, Hocking $\sqcup$, Hart D, Arden NK, Cooper C, Malik S, Fraser WD, Hartikainen AL, Zhai G, Macdonald HM, Forouhi NG Loos RJ, Reid DM, Hakim A, Dennison E, Liu Y, Power C, Stevens $H E$, Jaana L, Vasan RS, Soranzo N, Bojunga J, Psaty BM, Lorentzon M, Foroud T, Harris TB, Hofman A, Jansson JO, Cauley JA, Uitterlinden $A G$, Gibson $Q$, Järvelin MR, Karasik D, Siscovick DS, Econs MJ, Kritchevsky SB, Florez JC, Todd JA, Dupuis J, Hyppönen $E$, Spector TD. Common genetic determinants of vitamin $D$ insufficiency: a genome-wide association study. Lancet 2010;376: 180-8.

16. Ahn J, Yu K, Stolzenberg-Solomon R, Simon KC, McCullough ML, Gallicchio L, Jacobs EJ, Ascherio A, Helzlsouer K, Jacobs KB, Li Q, Weinstein SJ, Purdue M, Virtamo J, Horst R, Wheeler W, Chanock S, Hunter DJ, Hayes RB, Kraft P, Albanes D. Genome-wide association study of circulating vitamin D levels. Hum Mol Genet 2010;19: 2739-45.

17. Lu L, Bennett DA, Millwood IY, Parish S, McCarthy MI, Mahajan A, Lin X, Bragg F, Guo Y, Holmes MV, Afzal S, Nordestgaard BG, Bian Z, Hill M, Walters RG, Li L, Chen Z, Clarke R. Association of vitamin $D$ with risk of type 2 diabetes: a Mendelian randomisation study in European and Chinese adults. PLoS Med 2018;15:e1002566.

18. Mokry LE, Ross S, Ahmad OS, Forgetta V, Smith GD, Goltzman D, Leong A, Greenwood CM, Thanassoulis G, Richards JB. Vitamin D and risk of multiple sclerosis: a Mendelian randomization study. PLoS Med 2015;12:e1001866.

19. Ong JS, Hwang LD, Cuellar-Partida G, Martin NG, Chenevix-Trench G, Quinn MCJ, Cornelis MC, Gharahkhani P, Webb PM, MacGregor S; Ovarian Cancer Association Consortium. Assessment of moderate coffee consumption and risk of epithelial ovarian cancer: a Mendelian randomization study. Int J Epidemiol 2018;47:450-9.

20. Afzal S, Brøndum-Jacobsen P, Bojesen SE, Nordestgaard BG. Genetically low vitamin D concentrations and increased mortality: Mendelian randomisation analysis in three large cohorts. BMJ 2014;349:96330.

21. Berry DJ, Vimaleswaran KS, Whittaker JC, Hingorani AD, Hyppönen E. Evaluation of genetic markers as instruments for Mendelian randomization studies on vitamin D. PLoS One 2012;7:e37465.

22. Jolliffe DA, Walton RT, Griffiths CJ, Martineau AR. Single nucleotide polymorphisms in the vitamin $D$ pathway associating with circulating concentrations of vitamin D metabolites and non-skeletal health outcomes: review of genetic association studies. J Steroid Biochem Mol Biol 2016;164:18-29.

23. Kweon S, Kim Y, Jang MJ, Kim Y, Kim K, Choi S, Chun C, Khang $\mathrm{YH}$, Oh K. Data resource profile: the Korea National Health and Nutrition Examination Survey (KNHANES). Int J Epidemiol 2014;43: 69-77.

24. Friedewald WT, Levy Rl, Fredrickson DS. Estimation of the concentration of low-density lipoprotein cholesterol in plasma, without use of the preparative ultracentrifuge. Clin Chem 1972;18: 499-502.

25. Holick MF. Vitamin D deficiency. N Engl J Med 2007;357:266-81. 26. Cuellar-Partida G, Williams KM, Yazar S, Guggenheim JA, Hewitt AW, Williams C, Wang JJ, Kho PF, Saw SM, Cheng CY, Wong TY, Aung $T$, Young TL, Tideman JW, Jonas JB; Consortium for Refractive Error and Myopia (CREAM), Mitchell P, Wojciechowski R, Stambolian D, Hysi P, Hammond CJ, Mackey DA, Lucas RM, MacGregor S. Genetically low vitamin D concentrations and myopic refractive error: a Mendelian randomization study. Int J Epidemiol 2017;46: 
1882-90.

27. Korea Centers for Disease Control and Prevention. Standard Operating Procedures of Korea Biobank Network. Cheongju: Korea Centers for Disease Control and Prevention; 2015.

28. Lee $\mathrm{SH}$, Kang Ml, Ahn SH, Lim KH, Lee GE, Shin ES, Lee JE, Kim BJ, Cho EH, Kim SW, Kim TH, Kim HJ, Yoon KH, Lee WC, Kim GS, Koh JM, Kim SY. Common and rare variants in the exons and regulatory regions of osteoporosis-related genes improve osteoporotic fracture risk prediction. J Clin Endocrinol Metab 2014;99: E2400-11.

29. Kim OY, Moon J, Jo G, Kwak SY, Kim JY, Shin MJ. Apolipoprotein A5 3'-UTR variants and cardiometabolic traits in Koreans: results from the Korean genome and epidemiology study and the Korea National Health and Nutrition Examination Survey. Nutr Res Pract 2018;12:61-8.

30. Jiang X, O'Reilly PF, Aschard H, Hsu YH, Richards JB, Dupuis J, Ingelsson E, Karasik D, Pilz S, Berry D, Kestenbaum B, Zheng J, Luan J, Sofianopoulou E, Streeten EA, Albanes D, Lutsey PL, Yao L, Tang W, Econs MJ, Wallaschofski $H$, Völzke $H$, Zhou A, Power C, McCarthy MI, Michos ED, Boerwinkle E, Weinstein SJ, Freedman ND, Huang WY, Van Schoor NM, van der Velde N, Groot LC, Enneman A, Cupples LA, Booth SL, Vasan RS, Liu CT, Zhou Y, Ripatti S, Ohlsson C, Vandenput L, Lorentzon M, Eriksson JG, Shea MK, Houston DK, Kritchevsky SB, Liu Y, Lohman KK, Ferrucci L, Peacock M, Gieger C, Beekman M, Slagboom E, Deelen J, Heemst DV, Kleber ME, März W, de Boer IH, Wood AC, Rotter Jl, Rich SS, Robinson-Cohen C, den Heijer M, Jarvelin MR, Cavadino A, Joshi PK, Wilson JF, Hayward C, Lind L, Michaëlsson K, Trompet S, Zillikens MC, Uitterlinden AG, Rivadeneira F, Broer L, Zgaga L, Campbell $H$, Theodoratou $E$, Farrington SM, Timofeeva M, Dunlop MG, Valdes AM, Tikkanen E, Lehtimäki $T$, Lyytikäinen LP, Kähönen $M$, Raitakari OT, Mikkilä V, Ikram MA, Sattar N, Jukema JW, Wareham NJ, Langenberg C, Forouhi NG, Gundersen TE, Khaw KT, Butterworth AS, Danesh J, Spector T, Wang TJ, Hyppönen E, Kraft P, Kiel DP. Genome-wide association study in 79,366 European-ancestry individuals informs the genetic architecture of 25 -hydroxyvitamin D levels. Nat Commun 2018;9:260.

31. Kim D, Kim J. Age and sex differences in the relationship between serum 25-hydroxyvitamin $D$ and hypertension in the general Korean population. Eur J Clin Nutr 2016;70:326-32.

32. Kim MK, II Kang M, Won Oh K, Kwon HS, Lee JH, Lee WC, Yoon $\mathrm{KH}$, Son $\mathrm{HY}$. The association of serum vitamin $\mathrm{D}$ level with presence of metabolic syndrome and hypertension in middle-aged Korean subjects. Clin Endocrinol (Oxf) 2010;73:330-8.

33. Forman JP, Giovannucci $E$, Holmes $M D$, Bischoff-Ferrari $H A$ Tworoger SS, Willett WC, Curhan GC. Plasma 25-hydroxyvitamin D levels and risk of incident hypertension. Hypertension 2007;49: 1063-9.

34. Scragg $R$, Sowers $M$, Bell $C$; Third National Health and Nutrition Examination Survey. Serum 25-hydroxyvitamin D, diabetes, and ethnicity in the Third National Health and Nutrition Examination Survey. Diabetes Care 2004;27:2813-8.

35. Awumey EM, Mitra DA, Hollis BW, Kumar R, Bell NH. Vitamin D metabolism is altered in Asian Indians in the southern United States: a clinical research center study. J Clin Endocrinol Metab 1998;83 169-73.

36. Verbanck M, Chen CY, Neale B, Do R. Detection of widespread horizontal pleiotropy in causal relationships inferred from
Mendelian randomization between complex traits and diseases. Nat Genet 2018;50:693-8.

37. Dastani Z, Li R, Richards B. Genetic regulation of vitamin D levels. Calcif Tissue Int 2013;92:106-17.

38. Teslovich TM, Musunuru K, Smith AV, Edmondson AC, Stylianou IM, Koseki M, Pirruccello JP, Ripatti S, Chasman DI, Willer CJ, Johansen CT, Fouchier SW, Isaacs A, Peloso GM, Barbalic M, Ricketts SL, Bis JC, Aulchenko YS, Thorleifsson G, Feitosa MF, Chambers J, Orho-Melander M, Melander O, Johnson T, Li X, Guo X, Li M, Shin Cho Y, Jin Go M, Jin Kim Y, Lee JY, Park T, Kim K, Sim X, Twee-Hee Ong $R$, Croteau-Chonka DC, Lange LA, Smith JD, Song $K$, Hua Zhao J, Yuan X, Luan J, Lamina C, Ziegler A, Zhang W, Zee RY, Wright AF, Witteman JC, Wilson JF, Willemsen G, Wichmann HE, Whitfield $J B$, Waterworth DM, Wareham NJ, Waeber G, Vollenweider P, Voight BF, Vitart V, Uitterlinden AG, Uda M, Tuomilehto J, Thompson JR, Tanaka T, Surakka I, Stringham HM, Spector TD, Soranzo N, Smit $J \mathrm{H}$, Sinisalo J, Silander K, Sijbrands E, Scuteri A, Scott J, Schlessinger D, Sanna S, Salomaa V, Saharinen J, Sabatti C, Ruokonen A, Rudan I, Rose LM, Roberts R, Rieder M, Psaty BM, Pramstaller PP, Pichler I, Perola M, Penninx BW, Pedersen NL, Pattaro C, Parker AN, Pare G, Oostra BA, O'Donnell CJ, Nieminen MS, Nickerson DA, Montgomery GW, Meitinger T, McPherson R, McCarthy Ml, McArdle W, Masson D, Martin NG, Marroni F, Mangino M, Magnusson PK, Lucas $\mathrm{G}$, Luben $\mathrm{R}$, Loos R, Lokki ML, Lettre $\mathrm{G}$, Langenberg $\mathrm{C}$, Launer $\sqcup$, Lakatta EG, Laaksonen R, Kyvik KO, Kronenberg F, König IR, Khaw KT, Kaprio J, Kaplan LM, Johansson A, Jarvelin MR, Janssens AC, Ingelsson $\mathrm{E}$, Igl W, Kees Hovingh G, Hottenga JJ, Hofman A, Hicks AA, Hengstenberg C, Heid IM, Hayward C, Havulinna AS, Hastie ND, Harris TB, Haritunians T, Hall AS, Gyllensten U, Guiducci C, Groop LC, Gonzalez E, Gieger C, Freimer NB, Ferrucci L, Erdmann J, Elliott $P$, Ejebe KG, Döring A, Dominiczak AF, Demissie $S$, Deloukas $P$, de Geus EJ, de Faire U, Crawford G, Collins FS, Chen YD, Caulfield MJ, Campbell H, Burtt NP, Bonnycastle LL, Boomsma DI, Boekholdt SM, Bergman RN, Barroso I, Bandinelli S, Ballantyne CM, Assimes TL, Quertermous T, Altshuler D, Seielstad M, Wong TY, Tai ES, Feranil AB, Kuzawa CW, Adair LS, Taylor HA Jr, Borecki IB, Gabriel SB, Wilson JG, Holm H, Thorsteinsdottir U, Gudnason V, Krauss RM, Mohlke $\mathrm{KL}$, Ordovas JM, Munroe PB, Kooner JS, Tall AR, Hegele RA, Kastelein JJ, Schadt EE, Rotter Jl, Boerwinkle E, Strachan DP, Mooser V, Stefansson K, Reilly MP, Samani NJ, Schunkert H, Cupples LA, Sandhu MS, Ridker PM, Rader DJ, van Duijn CM, Peltonen L, Abecasis GR, Boehnke M, Kathiresan S. Biological, clinical and population relevance of 95 loci for blood lipids. Nature 2010;466:707-13.

39. Cheng JB, Levine MA, Bell NH, Mangelsdorf DJ, Russell DW. Genetic evidence that the human CYP2R1 enzyme is a key vitamin $D$ 25-hydroxylase. Proc Natl Acad Sci U S A 2004;101:7711-5.

40. Bikle D. Vitamin D: production, metabolism, and mechanisms of action. In: Feingold KR, Anawalt B, Boyce A, Chrousos G, Dungan K, Grossman A, Hershman JM, Kaltsas G, Koch C, Kopp P, Korbonits M, McLachlan R, Morley JE, New M, Perreault L, Purnell J, Rebar $R$, Singer $F$, Trence DL, Vinik A, Wilson DP, editors. Endotext. South Dartmouth (MA): MDText.com, Inc.; 2000.

41. Burgess S, Bowden J, Fall T, Ingelsson E, Thompson SG. Sensitivity analyses for robust causal inference from Mendelian randomization analyses with multiple genetic variants. Epidemiology 2017;28:30-42.

42. Nitsch D, Molokhia M, Smeeth L, DeStavola BL, Whittaker JC, Leon DA. Limits to causal inference based on Mendelian randomization: a comparison with randomized controlled trials. Am J Epidemiol 
2006;163:397-403.

43. Anderson D, Holt BJ, Pennell CE, Holt PG, Hart PH, Blackwell JM. Genome-wide association study of vitamin D levels in children: replication in the Western Australian Pregnancy Cohort (Raine) study. Genes Immun 2014;15:578-83.
44. Sapkota BR, Hopkins R, Bjonnes A, Ralhan S, Wander GS, Mehra NK, Singh JR, Blackett PR, Saxena R, Sanghera DK. Genome-wide association study of $25(\mathrm{OH})$ vitamin $D$ concentrations in Punjabi Sikhs: results of the Asian Indian diabetic heart study. J Steroid Biochem Mol Biol 2016;158:149-56. 